\title{
清华大学物理系在原子分子结构、光谱及动力学研 究方面的新进展
}

\author{
莫宇翔* \\ 清华大学物理系, 北京 100084 \\ *E-mail: ymo@mail.tsinghua.edu.cn \\ 收稿日期: 2011-01-20; 接受日期: 2011-02-18
}

\begin{abstract}
摘要
进展.

关键词原子分子结构, 激光光谱, 电子能量谱, Raman 光谱, 分子动力学

PACS: $\quad$ 33.20.Wr, 33.20.Fb, 34.80.Gs, 33.20.Ni, 31.15.-p
\end{abstract}

该文简短的描述了清华大学物理系的部分老师最近几年在原子分子结构、光谱及动力学领域的研究

原子分子结构、光谱及动力学的研究产生了科学 和技术中许多具有深远意义的进展, 如: 量子力学, 激光技术等; 它也是最具应用背景的基础学科之一. 这门学科具有实验和理论研究紧密相联系的特点, 学习这门学科的学生在实验能力和理论分析上都受 到非常好的训练, 能成为高素质的科学和技术人才. 清华大学物理系有多名教授从事这方面的研究, 取 得了丰硕的成果并培养了一批具有深厚原子分子物 理实验和理论知识的高科技人才. 本文介绍清华大 学物理系最近在此方面研究的主要进展, 较具体的 研究成果可以参阅有关文献.

\section{1 双原子分子激光态光谱和动力 学 $^{[1 \text { 6] }}$}

双原子分子的光谱及动力学对于了解分子电子 结构有非常重要的意义, 它的研究对实验及理论的 发展都有重要的影响. 李丽教授 ${ }^{[1 \sim 6]}$ 多年来一直从事
碱金属分子激光光谱和动力学研究. 她创立了微扰 增强双共振激光光谱技术, 并用此项技术进行一系 列重要研究. 该技术解决了双原子分子三重态无法 用通常的激光光谱技术研究的难题. 运用该技术, 她 成功地实验观察和研究了 $\mathrm{Na}_{2}, \mathrm{Li}_{2}, \mathrm{~K}_{2}$ 和 $\mathrm{Cs}_{2}$ 等分 子的 40 多个三重态, 其中包括在理论和实验上都具 有重要意义的 $\mathrm{a}^{3} \Sigma_{\mathrm{u}}{ }^{+}$态. 另外, 她和同事首次用高分 辨光谱观测到 $\mathrm{Na}_{2}, \mathrm{Li}_{2}$ 和 $\mathrm{K}_{2}$ 分子的双电子激发态, 这 些双激发态和同样能区的里德堡态的物理行为有很 大的差异, 如: 由于电子结构和离子基态有很大差异, 不发生自电离. 在分子激发态动力学方面的研究上, 李丽和她的学生首次在态-态水平观测到单 三重微 扰能级在碰撞传能过程中的“通道”效应, 首次实验 观测到并分析了 $\mathrm{Na}_{2}\left(3^{3} \Pi_{\mathrm{g}}\right)$ 态的由势能曲线避免交叉 产生的强烈预解离, 能级寿命小到 $250 \mathrm{fs}$ (通常为几 十纳秒). 李丽教授的另一个重要贡献是用高分辨激 光光谱研究分子体系的量子干涉、Autler-Townes

引用格式: 莫宇翔. 清华大学物理系在原子分子结构、光谱及动力学研究方面的新进展. 中国科学: 物理学 力学 天文学, 2011, 41: 501-506 Mo Y X. Advances in studies on spectra and dynamics of atoms and molecules in Department of Physics in Tsinghua University (in Chinese). Sci Sin Phys Mech Astron, 2011, 41: 501-506, doi: 10.1360/132011-88 
(A-T)分裂和电磁感应透明. 她和坦普大学合作用高 分辨激光光谱研究分子体系 A-T 分裂, 首次用三共 振在分子体系分辨出光场作用下转动能级的磁子能 级的分裂, 后来又首次用电磁感应透明测量分子跃 迁偶极矩. 她首次在分子体系观察到双光子跃迁中 的电磁感应透明. 在李丽老师已有研究结果的基础 上, 物理系新引进的戴星灿助理教授将研究铭双原 子分子的高激发态和相干控制.

\section{$2 \mathrm{XUV}$ 激光分子光谱及动力学}

分子物理的主要基础是 Born-Oppenheimer(BO) 近似, 即: 电子运动和核振动可以分开处理, $\mathrm{BO}$ 近似 适应于分子中两个势能面间隔较大的情况，当两个 势能面的间隔和核振动的能量相近时，核振动与电 子运动可能会发生较强的耦合或非绝热相互作用, $\mathrm{BO}$ 近似不再成立, 如何描述分子中电子-振动耦合是 分子物理中一个没有完全解决的问题; 在有较强电 子-振动耦合下, 分子光谱和动力学的研究将对于研 究这个问题有非常大的意义. 物理系莫宇翔教授利 用高分辨光电子能谱技术和激光四波混频产生真空 紫光激光(VUV/XUV)技术研究了一系列分子离子的 电子-振动耦合光谱 ${ }^{[7 ~ 12]}$, 如: $\mathrm{PH}_{3}{ }^{+}, \mathrm{C}_{2} \mathrm{H}_{2}{ }^{+} / \mathrm{C}_{2} \mathrm{D}_{2}{ }^{+}, \mathrm{CH}_{3}$ $\mathrm{CN}^{+} / \mathrm{CD}_{3} \mathrm{CN}^{+}$, 和 $\mathrm{BrCN}^{+}$等, 这些光谱增加了我们对 分子电子结构的认识. 对 $\mathrm{PH}_{3}{ }^{+}$, 其伞形振动有一个较 低的势垒 $\left(1084 \mathrm{~cm}^{-1}\right)$, 他们第一次观察到了由于这个 势垒导致的能级分裂 $\left(5.8 \mathrm{~cm}^{-1}\right)$, 也观察到了它的 $\mathrm{P}-\mathrm{H}$ 对称伸缩和 $\mathrm{PH}_{3}{ }^{+}$的反对称弯曲振动, 它们的基频分 别是: 2461.6 和 $1043.9 \mathrm{~cm}^{-1} . \mathrm{C}_{2} \mathrm{H}_{2}{ }^{+}$是一个具有电子振动-自旋-转动耦合的典型四原子分子, 他们测量了 从振动基态到 $1800 \mathrm{~cm}^{-1}$ 激发的耦合能级, 包括这个 离子对称 $\left(v_{4}\right)$ 和反对称振动 $\left(v_{5}\right)$ 的基频, 倍频和它们 的和频, 从实验结果中他们得到了与此相关的光谱 参数, 这些光谱参数为精确的理论计算提供了样板 分子. 对于 $\mathrm{CH}_{3} \mathrm{CN}^{+} / \mathrm{CD}_{3} \mathrm{CN}^{+}$, 由于电子态是简并的, 非对称的振动将耦合电子态, 形成电子-振动-自旋耦 合态(Jahn-Teller 效应), 他们测量了这个分子的高分 辨光电子能谱, 发现了 Jahn-Teller 效应导致的能级分 裂情况, 并用所谓 diabatic 模型从理论上计算了这个 分子的电子-振动-自旋耦合能级, 理论结果与实验结 果在能量较低的范围符合较好.

分子超激发态是指分子内能超过分子电离能的
态, 它有非常强的非绝热相互作用. 离子对解离是分 子超激发态衰变的一个重要通道. 莫宇翔教授的小 组利用 VUV/XUV 激光和离子速度成像技术研究了 一系列重要双原子分子 $\mathrm{F}_{2}, \mathrm{Cl}_{2}, \mathrm{O}_{2}, \mathrm{HCl}$ 和三原子分子 $\mathrm{SO}_{2}, \mathrm{H}_{2} \mathrm{~S}$ 和 $\mathrm{N}_{2} \mathrm{O}$ 的离子对光解动力学. 他们发现离子 对的解离一般都是通过分子 Rydberg 态的预解离进 行的，通过测量产物的空间分布，可以确定受激发的 Rydberg 态对称性; 通过测量产物的态分布, 可以了 解分子解离过程中的动力学性质, 这些研究增加了 我们关于分子离子对解离和分子超激发态的知识. 图 1 是 $\mathrm{Cl}_{2}$ 分子在 $\mathrm{XUV}$ 激光作用下解离成离子对, 通 过实验获得 $\mathrm{Cl}^{-}\left({ }^{1} \mathrm{~S}_{0}\right)$ 的速度成像，并通过 Abel 变换获 得的碎片切片成像. 通过这样的数据可以获得有关 $\mathrm{Cl}_{2}$ 解离成离子对的详细动力学信息.

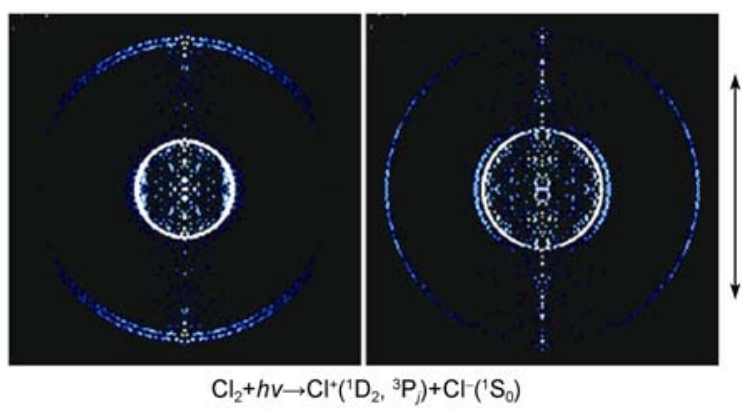

图 $1 \mathrm{Cl}_{2}$ 在 XUV 激光的照射下解离成两个碎片的切片 成像图

外环对应的产物是 $\mathrm{Cl}^{+}\left({ }^{3} \mathrm{P}_{J=0,1,2}\right)$, 内环中比较亮的部分对应的产物 是 $\mathrm{Cl}^{+}\left({ }^{1} \mathrm{D}_{2}\right)$, 比较暗的部分是来自于 $\mathrm{Cl}_{2}(\mathrm{v}=1)$ 或热带. 左, 右图对 应的 XUV 激光能量分别是: 108425.9 和 $109101.0 \mathrm{~cm}^{-1}$. 图 1 中的 箭头表示 XUV 激光的偏振方向. 从图中可得到碎片的角分布和 平动能分布等动力学信息, 更详细的说明可见文献[12]

Figure 1 The slice images of $\mathrm{Cl}^{-}\left({ }^{1} \mathrm{~S}_{0}\right)$ from the photodissociation of $\mathrm{Cl}_{2}$. The large rings correspond to the production of $\mathrm{Cl}^{+}\left({ }^{3} \mathrm{P}_{J=0,1,2}\right)$. The small rings correspond to the production of $\mathrm{Cl}^{+}\left({ }^{1} \mathrm{D}_{2}\right)$, in which the relative weak rings originated from $\mathrm{Cl}_{2}(\mathrm{v}=1)$ or the hot bands. The photon energies used for the left and right figure are 108425.9 and $109101.0 \mathrm{~cm}^{-1}$, respectively. The arrow represents the polarization direction of the XUV laser. From the two figures, angular distribution of the fragments and also the translational energy distribution of the fragments can be determined. For more details please see Ref. (12).

\section{3 分子振动光谱研究}

\section{1 高激发振动态研究}

分子振动高激发态对于了解分子内的核运动有 非常重要的意义. 物理系吴国祯教授用代数的方法 
研究了一些三原子分子振动高激发态的解离和导致 同分异构物的内旋转运动. 若将体系的哈密顿量表 示为陪集空间的运动量, 动力学过程就可表示为陪 集空间中的轨迹, 这是一个非线性的力学体系, 非线 性力学的许多概念, 如分叉, 表示混沌程度的李雅普 诺夫指数等, 都可以用于对高激发振动态的研究. 这 个方法能结合非线性力学的方法, 提供许多分子谱 学实验结果的物理图象, 而这是传统的求解薛定谔 波函数的思维方法所难以体现的. 吴国祯教授的方 法立足于用(半)经典的方法, 利用分子谱学的实验数 据, 从大的能量的范围来构建物分子中核运动的物 理图像 ${ }^{[13 \sim 15]}$.

\section{2 拉曼峰强研究}

拉曼过程中分子的激发中间态一般是电子激发 态, 它们不是本征态, 是所有激发本征态波函数的叠 加, 或说是波包. 因此, 人们很难用一般求本征态的 量子力学方法, 来求取激发中间态. 在实验上, 激发 中间态的电子结构信息应会在拉曼光谱的峰强中有 所体现. 吴国祯教授和他的学生创立了一个从拉曼 峰强中求取分子键极化率的方法 ${ }^{[16 ~ 18]}$. 从求得的键 极化率, 可以得到许多用别的方法难以获得的细致 的分子内电子行为. 从量子化学方法求得的键电荷密 度, 体现的是分子在基态时的电子分布, 而从拉曼峰 强求得的键极化率反映的是分子处在激发态弛豫过 程中, 电子受核运动调制的反响. 因此, 对它们的对 比可提供拉曼过程中, 分子中的电荷分布随时间变 化的信息. 另外, 这个方法还可以用于研究表面增强 拉曼过程中，电荷分布随时间变化的信息. 他们发现， 弛豫后的键极化率和电子基态的键电荷密度成比例, 这就是说, 拉曼的峰强中蕴含着分子基态的电子结 构信息. 这是过去未为人们所认识到的. 他们正在把 这个方法推广来研究拉曼旋光的领域, 希望能了解 分子中细致的电、磁偶极矩以及四极矩的耦合信息.

\section{4 电子动量谱学研究}

电子动量谱能够测量原子分子中不同轨道上的 电子在动量空间上的密度分布, 这对于了解分子中 的电子关联, 电子结构有重要的作用. 物理系邓景康 教授利用他们研制的高分辨电子动量谱仪测量了一 些重要分子的电子动量谱并结合理论计算对这些动
量谱进行了分析 ${ }^{[19 ~ 24]}$.

他们对苯甲醇分子和环已烷分子的构象问题进 行了电子动量谱学的实验研究和理论分析, 对于苯 甲醇分子, 其在常温下应存在两种稳定构象 Gauche 和 Trans, 比例约为 $69: 31$, 且两种构象在低动量区 分布有一定差异; 对环己烷, 证实其“椅式”结构是常 温下唯一的稳定构型.

他们比较了利用非相对论, scalar 相对论以及 spin-orbit 相对论 3 种不同方法得到的 $\mathrm{I}_{2}$ 与 $\mathrm{Au}_{2}$ 分子 的价轨道的结合能和理论动量谱, 发现相对论效应 影响它们的能级分布以及轨道波函数分布. 这些影 响是通过原子轨道传递给分子轨道的. $\mathrm{Au}_{2}$ 分子中的 相对论效应要远强于 $\mathrm{I}_{2}$ 分子, 主要表现为 $\mathrm{Au}_{2}$ 分子自 旋-轨道之间的耦合更为复杂.

他们对 $\mathrm{W}(\mathrm{CO})_{6}$ 进行了电子动量谱学测量, 并结 合非相对论和相对论量子化学计算进行了理论分析. 结果表明: 相对论效应对 $\mathrm{W}(\mathrm{CO})_{6}$ 分子外价轨道的电 子动量分布的影响较为明显, 相对论效应使得 $\mathrm{W}(\mathrm{CO})_{6}$ 分子的部分外价轨道膨胀或收缩. 他们还对 $\mathrm{W}(\mathrm{CO})_{6}$ 分子外价轨道进行了排序, 并指出其 HOMO 轨道的低动量区的上尧现象可能是由分子振动引起 的，而实验结果并不支持之前认为的扭曲波效应. 对 二茂铁分子的研究表明, 它的相对论效应并不明显, 其重叠型和交错型两种构象在球平均的轨道动量分 布上也没有明显差异, 其外价轨道动量分布的理论 值与实验值的差异主要是由扭曲波效应引起的.

他们对萗分子的电子动量谱学实验和量子化学 计算研表明：其在低动量区的电子动量分布实验值 较理论值高, 通过分子轨道密度图可以看出菜的相 关分子轨道为 $\pi$ 型分布, 因此这类现象应归结于扭曲 波效应。

\section{5 原子、分子结构的理论研究}

李家明院士的小组围绕着研究发展量子多体理 论和计算方法, 对原子、分子、团簇体系的物理性质 和有关动力过程进行定量的理论计算和描述. 他们 最近的主要成果如下 ${ }^{[25 ~ 30]}$ :

(1) 提出可行的原子体系“准”完备基建立方案, 该方案可对原子体系进行精密计算; 定量阐明造成 原子体系细结构分裂的 4 种机制(即自旋-轨道相互作 用、电子交换作用的相对论校正、电子关联作用和 
Breit 相互作用)间相互竞争. 研究了类 $\mathrm{Mg}$ 、类 $\mathrm{N}$ 等 原子系列; 展示了用准完备基进行二阶微扰精密计 算 AC Stark 系数的优越性. 可以进一步计算任何真实 原子基态、激发态的动态极化系数; 从而可以系统而 精确地决定最佳光格子光频率(魔数波长); 同时也将 为精密处理“原子钟”的黑体辐射校正提供理论数据.

（2）电子碰撞激发不论在量子多电子关联问题 的基础研究方面还是在实际应用方面都有重要意义. 在多电子强关联区域(即作用域)内利用变分准确处 理多电子相互作用，在作用域外利用 $\mathrm{R}$ 矩阵方法准 确地计算原子的所用重要能态(基态、激发态、连续 态). 以电子和 $\mathrm{Na}$ 原子散射为例, 系统阐明了靶的里 德堡态对散射截面的影响, 提出了一套低能电子散 射截面与高能 Born 近似截面接口的方案, 可以高效 地提供高质量截面数据; 计算了钠原子价电子 $3 \mathrm{~s}-3 \mathrm{p}$
以及内壳层电子 $2 \mathrm{p}-3 \mathrm{~s}$ 激发的高能电子碰撞截面. 在 多年研究成果的基础上，提出了一种提供原子参数 的“多快好省”方案; 向原子分子物理参数科学界总 结了我国在这方面的进展.

(3) 分子超激发态存在相互竞争的电离、解离通 道, 在电离辐射能量淀积过程中具有非常重要的作 用，具有很强的基础研究及实际意义. 在量子数亏损 理论框架下，应用多重散射自洽场方法和含时波包 演化法研究了 $\mathrm{F}_{2}$ 分子经过超激发态发生离子对解离 产生的 $\mathrm{F}^{-1}$ 离子产生效率谱, 给出了清楚的标识, 计算 得到相对强度和实验测量符合; 进一步分析解释了 速度成像所形成的不同“圆环”间的分支比，提出了 实验观测到的“两环”、“三环”是一种量子相干现象. 说明高分辨的激光光谱加上速度成像的实验方法可 以作为细致研究光反应的“显微镜”.

\section{参考文献}

1 Li L, Field R W. Direct observation of high-lying ${ }^{3} \Pi_{\mathrm{g}}$ states of the $\mathrm{Na}_{2}$ molecule by optical-optical double resonance. J Phys Chem, 1983 , 87(16): 3020-3022

2 Xie X, Sovkov V B, Lyyra A M, et al. Experimental investigation of the $\mathrm{Cs}_{2} a^{3} \Sigma_{u}{ }^{+}$triplet ground state: Multiparameter Morse long range potential analysis and molecular constants. J Chem Phys, 2009, 130(5): 051102

3 Xie F, Li D, Tyree L, et al. Observation and calculation of the $\mathrm{Cs}_{2} 2^{3} \Delta_{\mathrm{lg}}$ and $b^{3} \Pi_{0 \mathrm{u}}$ states. J Chem Phys, 2008, 128 (20): 204313

4 Li J, Liu Y, Dai X, Li L, et al. Relabeling and classification of the rydberg states. J Chem Phys, 2001, 114(18): 7859-7865

5 Li L, Wang X, Yang J, et al. Comment on "Experimental observation of spontaneous emission cancellation”. Phys Rev Lett, 2000, 84(17): 4016-4016

6 Li L, Qi P, Lazoudis A, et al. Observation of electromagnetically induced transparency in two-photon transitions of $\mathrm{K}_{2}$. Chem Phys Lett, 2005, 403(4-6): 262-267

7 Yang J, Li J, Hao Y S, et al. Inversion vibration of $\mathrm{PH}_{3}^{+}\left(\tilde{X}^{2} \mathrm{~A}_{2}^{\prime \prime}\right)$ studied by zero kinetic energy photoelectron spectroscopy. J Chem Phys, 2006, 125(5): 054311

8 Yang J, Mo Y. The Renner-Teller effect in $\mathrm{C}_{2} \mathrm{H}_{2}^{+}\left(\tilde{X}^{2} \Pi_{u}\right)$ studied by zero kinetic energy photoelectron spectroscopy. J Phys Chem A, 2006, 110(38): 11001-11009

9 Zhang S Y, Mo Y. Theoretical study of the Jahn-Teller effect in $\mathrm{CH}_{3} \mathrm{CN}^{+}\left(\mathrm{X}^{2} \mathrm{E}\right)$ and $\mathrm{CD}_{3} \mathrm{CN}^{+}\left(\mathrm{X}^{2} \mathrm{E}\right)$ : Multimode spin-vibronic energy level calculations. J Phys Chem A, 2009, 113(41): 10947-10954

10 Hao Y S, Zhou C, Mo Y. Velocity map imaging study of the $\mathrm{O}_{2}$ ion-pair production at $17.499 \mathrm{eV}$ : Simultaneous parallel and perpendicular Transitions. J Phys Chem A, 2005, 109(26): 5832-5835

11 Zhou C, Mo Y. Ion-pair dissociation of $\mathrm{N}_{2} \mathrm{O}$ in the 16.25-16.41 eV: Dynamics and electronic structure. J Chem Phys, 2008, 129(6): 064312

12 Hao Y S, Zhou C, Mo Y. Ion-pair dissociation dynamics of $\mathrm{Cl}_{2}$ in the range 13.26-13.73 eV studied by using XUV laser and the velocity map imaging method. J Phys Chem A, 2009, 113(11): 2294-2303

13 Fang C, Wu G Z. Dynamical similarity in the highly excited vibrations of HCP and DCP: The dynamical potential approach. J Mol Struct Theochem, 2009, 910(1-3): 141-147

14 Fang $\mathrm{C}$, Wu G Z. Global dynamical analysis of vibrational manifolds of $\mathrm{HOCl}$ and $\mathrm{HOBr}$ under anharmonicity and Fermi resonance: The 
dynamical potential approach. Chin Phys B, 2010, 19(1): 010509

15 Zhang C, Fang C, Wu G Z. Bending localization of nitrous oxide under anharmonicity and Fermi coupling: the dynamical potential approach. Chin Phys B, 2010, 19(11): 110513

16 吴国祯. 分子高激发振动一非线性和混沌的理论. 第二版. 北京: 科学出版社出版, 2008

17 Fang C, Wu G Z. Temporal Raman polarizabilities of piperidine in liquid and on the Ag surface with electromagnetic enhancement. J Mol Struct, 2009, 938(1-3): 336-340

18 Fang C, Wu G Z. Raman intensity interpretation of pyridine liquid and its adsorption on the Ag electrode via bond polarizabilities. Spectrochim Acta, 2010, A77(5): 948-953

19 Liu K, Ning C G, Deng J K. Combining relativistic quantum-chemistry theories and electron-momentum spectroscopy to study valence-electron structures of molecules. Phys Rev A, 2009, 80(2): 022716

20 Liu K, Ning C G, Deng J K. Electron momentum spectroscopy investigation on the HOMO and N-HOMO obitals of benzyl alcohol (in Chinese). J Atomic Molecular Phys, 2010, 27(2): 211-214 [刘昆, 宁传刚, 邓景康. 苯甲醇分子 HOMO 和 N-HOMO 轨道的电子动量谱 学研究. 原子与分子物理学报, 2010, 27(2): 211-214]

21 Shi L L, Ning C G, Deng J K. Theoretical electron momentum study on the influence of relativistic effects on the valence orbitals of UF6 (in Chinese). J Atomic Molecular Phys, 2010, 27(2): 195-202 [石砳磊, 宁传刚, 邓景康. UF 6 分子价轨道相对论效应的理论电子动量谱 学研究. 原子与分子物理学报, 2010, 27(2): 195-202]

22 Liu K, Ning C G, Deng J K. Interpretation of the experimental electron momentum spectra of $5 \mathrm{e}_{1 / 2}$ and $5 \mathrm{e}_{3 / 2}$ orbitals of CF3I with Relativistic Calculations. Chin Phys Lett, 2010, 27(7): 073403

23 Liu K, Ning C G, Shi L L, et al. Probing the distorted wave effects in (e, 2e) reaction for the outer valence orbitals of ferrocene (in Chinese). Acta Phys Sin, 2011, 60(2): 023402 [刘昆, 宁传刚, 石砳否, 等. 探测二茂铁外价轨道(e, 2e)反应中的扭曲波效应. 物理学报, 2011, 60(2): 023402]

24 Liu K, Ning C G, Luo Z H, et al. An experimental and theoretical study of the HOMO of W(CO)6: Vibrational effects on the electron momentum density distribution. Chem Phys Lett, 2010, 497(4-6): 229-233

25 Qing B, Cheng C, Gao X, et al. Full-relativistic multi-configuration self-consistent calculation of atomic structures and physical properties-Construction of quasi-complete basis sets and configuration interaction calculations (in Chinese). Acta Phys Sin, 2010, 59(7): 4547-4555 [青波, 程诚, 高翔, 等. 全相对论多组态原子结构及物理量的精密计算一构建准完备基以及组态相互作用. 物理学报, 2010, 59(7): 4547-4555]

26 Cheng C, Zhang X L, Gao X, et al. Theoretical study on mechanisms of anomalous fine structure in the magnesium isoelectronic sequence. J Phys B-At Mol Opt Phys, 2010, 43(10): 105001

27 Gao X, Li J M. The precision calculations of atomic polarizabilities: A relevant physical quantity in modern atomic frequency standard. Chin Phys Lett, 2010, 27(6): 063101

28 Gao X, Han X Y, Lan V, et al. Precision calculation of low-energy electron impact excitation cross sections of sodium. Phys Rev A, 2010, 81(2): 022703

29 Han X Y, Li Y M, Zhang H, et al. R-matrix treatment of high-energy electron-impact excitation processes: The generalized oscillator strengths for the Na 3s-3p and 2p-3s transitions. Phys Rev A, 2008, 78(5): 052702

30 Li J M, Gao X, Cheng C, et al. A scenario to provide atomic data for fusion research in the stage of precision physics. Plasma Sci Technol, 2010, 12: 335 (Also available in "AMPP09: Proceedings of the 3rd China-Japan Joint Seminar on Atomic and Molecular Processes in Plasma Atomic and Molecular Processes in Plasma (NIFS-PROC Series.”); Li J M, Han X Y. Progress of atomic and molecular physics for Chinese scientific data community. In: ICAMDATA-2008: 6th International Conference on Molecular Data and Their Applications. AIP Conference Proceedings, 2009. 1125: 3-17 


\title{
Advances in studies on spectra and dynamics of atoms and molecules in Department of Physics in Tsinghua University
}

\author{
MO YuXiang* \\ Department of Physics, Tsinghua University, Beijing 100084, China
}

This paper briefly reviews the recent advances on spectra and dynamics of atoms and molecules in department of physics in Tsinghua University. These studies have provided great insights into the electronic structures and dynamics of atoms and molecules using various experimental and theoretical methods.

atomic and molecular structure, laser spectroscopy, electron momentum spectroscopy, Raman spectroscopy, molecular dynamics

PACS: $33.20 . \mathrm{Wr}, 33.20 . \mathrm{Fb}, 34.80 . \mathrm{Gs}, 33.20 . \mathrm{Ni}, 31.15 .-\mathrm{p}$

doi: $10.1360 / 132011-88$ 